\title{
PERKEMBANGAN DESA BERDASARKAN INDEKS DESA MEMBANGUN DI KABUPATEN MEMPAWAH
}

\section{VILLAGE PROGRESS BY VILLAGE DEVELOPING INDEX IN MEMPAWAH REGENCY}

\author{
Franciscus Xaverius) $)^{1^{*}}$ \\ ${ }^{1}$ Bappeda Kabupaten Mempawah, \\ Jl. Chandramidi, Mempawah \\ *e-mail:verimoanbura@gmail.com
}

Diterima: 1 Juni 2021, Revisi 23 Juni 2021, Diterbitkan : 30 Juni 2021

\begin{abstract}
The Village Progress and Independence Status status is a measure of village classification to determine interventions, both budgets and village development policies. This study described the status of Village Progress and Independence based on the Village Developing Index (VDI) in Mempawah Regency from 2018 to 2020, namely to describe the condition of Village Status and Village Independence and identify the causes of the changes. The data were collected from the official documents and the interviews with relevant informant.. The data were analyzed deductively. Referring to the Village Developing Index in Mempawah Regency, the status of Village Progress and Independence has improved in Social, Economic, and Ecological aspects/environmental resilience. This increase was mainly marked by the emergence of several villages with Advanced and Independent IDM Status.
\end{abstract}

Keywords: Village, Develop, Index, Mempawah

\begin{abstract}
ABSTRAK
Status Kemajuan dan Kemandirian Desa adalah ukuran pengklasifikasian desa dalam rangka menentukan intervensi, baik anggaran maupun kebijakan Pembangunan Desa. Penelitian ini menggambarkan Status Kemajuan dan Kemandirian Desa berdasarkan Indeks Desa Membangun (IDM) di Kabupaten Mempawah dari tahun 2018 sampai tahun 2020 yaitu untuk menggambarkan kondisi Status Desa dan Kemandirian Desa dan mengidentifikasi penyebab perubahannya. Teknik pengumpulan data menggunakan studi literatur dan melakukan wawancara dengan narasumber terkait. Analisis data menggunakan deduksi kualitatif. Status Kemajuan Desa dan Kemandirian Desa yang ditandai dengan Indeks Desa Membangun di Kabupaten Mempawah telah mengalami peningkatan dengan semakin baiknya aspek Sosial, Ekonomi, dan Ekologi/ketahanan lingkungan. Peningkatan ini terutama ditandai dengan munculnya beberapa desa dengan Status IDM Maju dan Mandiri.
\end{abstract}

Kata kunci: Desa, Membangun, Indeks, Mempawah

\section{PENDAHULUAN}

Desa merupakan kesatuan masyarakat hukum yang memiliki batas wilayah yang berwenang untuk mengatur dan mengurus urusan pemerintahan, kepentingan masyarakat setempat berdasarkan prakarsa masyarakat, hak asal usul dan/atau hak tradisional yang diakui dan dihormati dalam sistem pemerintahan Negara Kesatuan Republik Indonesia (NKRI). Menurut Undang-undang Nomor 6 Tahun 2014 (Sari \& Oktavianor, 2020), status kemajuan dan kemandirian desa adalah ukuran pengklasifikasian desa 
dalam rangka menentukan intervensi, baik anggaran maupun kebijakan pembangunan desa. Selanjutnya, Pasal 5, Ayat 3 dari Peraturan Menteri Desa, Pembangunan Daerah Tertinggal Dan Transmigrasi No. 2 Tahun 2016 Tentang Indeks Desa Membangun menjelaskan bahwa status kemajuan dan kemandirian desa berdasarkan Indeks Desa Membangun ditetapkan melalui Surat Keputusan Direktur Jenderal Pembangunan dan Pemberdayaan Masyarakat Desa Kementerian Desa, Pembangunan Daerah Tertinggal, dan Transmigrasi Republik Indonesia.

Pada Prakata Buku Indeks Desa Membangun yang diterbitkan pada tahun 2015, Menteri Desa, Pembangunan Daerah Tertinggal, dan Transmigrasi mengatakan bahwa Indeks Desa Membangun (IDM) meletakkan prakarsa dan kuatnya kapasitas masyarakat sebagai basis utama dalam proses kemajuan dan keberdayaan desa yaitu meliputi aspek ketahanan sosial, ekonomi, dan ekologi. Menurut Hamidi et al., (2015), IDM merupakan indeks komposit dari ketiga aspek tersebut yang memiliki 22 variabel dan 52 indikator. Oleh karenanya, pencapaian IDM difokuskan pada upaya penguatan otonomi desa melalui pemberdayaan masyarakat (Hamidi et al., 2015) karena pemberdayaan masyarakat desa inilah yang akan menjadi tumpuan utama terjadinya proses peningkatan partisipasi yang berkualitas, peningkatan pengetahuan, dan peningkatan keterampilan, atau secara umum dapat disebut sebagai peningkatan kapasitas dan kapabilitas masyarakat desa itu sendiri.

Berdasarkan IDM, desa terdapat 5 (lima) diklasifikasikan kedalam desa mandiri, desa maju, desa berkembang, desa tertinggal, dan desa sangat tertinggal. Klasifikasi desa tersebut dibuat untuk menunjukkan keragaman karakter setiap desa dan menajamkan status perkembangan desa sekaligus rekomendasi kebijakan yang diperlukan (Hamidi et al., 2015). Klasifikasi desa ini berfungsi untuk menunjukkan keragaman karakter setiap desa dalam rentang skor 0,27-0,92. Klasifikasi dalam 5 status desa tersebut juga digunakan untuk menajamkan penetapan status perkembangan desa dan sekaligus rekomendasi intervensi kebijakan yang diperlukan. Status desa tertinggal, misalnya, dijelaskan dalam dua status yaitu, desa tertinggal dan desa sangat tertinggal dengan situasi dan kondisi setiap desa membutuhkan pendekatan dan intervensi kebijakan yang berbeda (Hamidi et al., 2015). Klasifikasi status desa tersebut ditetapkan dengan ambang batas sebagai berikut (Tabel 1):

Tabel 1. Klasifikasi Status Desa

\begin{tabular}{|c|c|c|}
\hline No. & Status Desa & Ambang Batas \\
\hline 1. & $\begin{array}{l}\text { Desa Sangat } \\
\text { Tertingqal }\end{array}$ & $\leq 0,491$ \\
\hline 2. & Desa Tertinggal & $<0,491$ dan $\leq 0,599$ \\
\hline 3. & Desa Berkembang & $>0,599$ dan $\leq 0,707$ \\
\hline 4. & Desa Maju & $>0,707$ dan $\leq 0,815$ \\
\hline 5. & Desa Mandiri & $>0,815$ \\
\hline
\end{tabular}

Berdasarkan status IDM, terdapat beberapa karakteristik desa. Desa sangat tertinggal atau desa tertinggal mempunyai ciri ketertinggalan pembangunan, pengembangan, pengadaan, pemeliharaan, dan pengembangan sarana pembangunan terhadap aktivitas perekonomian dalam rangka mengadakan kegiatan produksi, distribusi, dan pemasaran. Desa berkembang memiliki ciri berupa pembangunan serta pengembangan seluruh infrastruktur perekonomian 
mulai dari produksi, retribusi, dan pemasaran serta berusaha untuk dapat menjadi lumbung pangan dan usaha perekonomian masyarakat desa. Desa Maju atau Desa Mandiri memiliki kekhasan berupa pembangunan, pengembangan serta pemeliharaan inftrastruktur desa yang berbasis pada angka produktifitas yang difokuskan dalam sebuah produk unggulan (Sukarno, 2020).

Status desa terkait dengan situasi dan kondisi dapat dikaitkan pula dengan faktor kerentanan dan kemampuan desa dalam mengelola potensi yang dimilikinya. Apabila terjadi tekanan faktor kerentanan seperti goncangan ekonomi, bencana alam, atau konflik sosial, maka akan terjadi penurunan status desa. Misalnya, jika faktor bencana alam tanpa penanganan yang cepat dan tepat, atau konflik sosial terus terjadi berkepanjangan, maka status desa berpeluang untuk menurun. kemampuan desa mengelola daya, terutama potensi, informasi/nilai, inovasi/prakarsa, dan kewirausahaan akan mendukung kenaikan status desa misalnya dari Desa Berkembang menjadi Desa Maju (Hamidi et al., 2015).

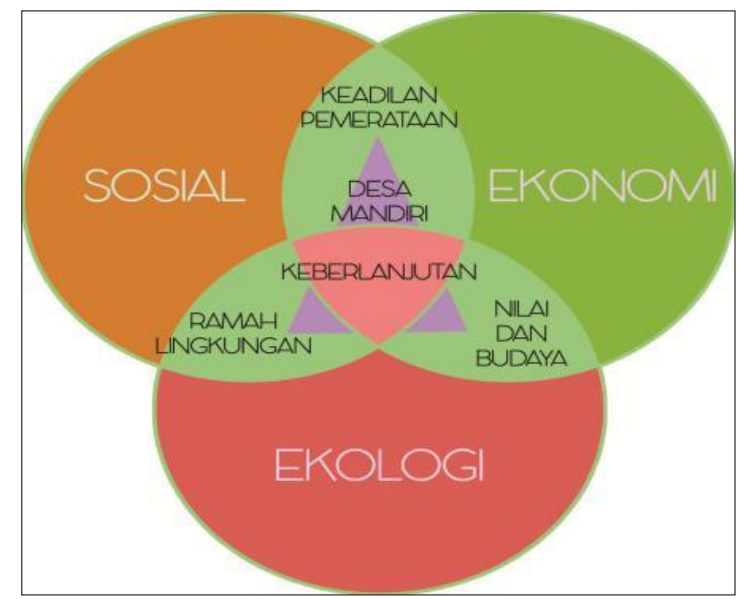

Sumber: (Hamidi et al., 2015)

Gambar 1. Tiga dimensi IDM
Pembangunan seharusnya mengarah kepada peningkatan kesejahteraan masyarakat pedesaan melalui pemberdayaan masyarakat desa. Pemberdayaan masyarakat berupaya untuk meningkatkan kualitas sumber daya manusia (SDM) terutama dalam membentuk dan merubah perilaku masyarakat untuk mencapai kehidupan yang lebih berkualitas (Ulumiyah et al., 2013).

Untuk mengurangi jumlah desa tertinggal dan meningkatkan jumlah desa mandiri, maka problem yang penting untuk diselesaikan ialah masalah kemiskinan. Problem ini selalu mendapatkan perhatian lebih dari Pemerintah Indonesia. Hal ini terjadi karena pemerintah sadar akan pentingnya mengatasi persoalan kemiskinan. Jika gagal mengatasi persoalan ini, maka dapat menimbulkan munculnya berbagai persoalan sosial, ekonomi dan politik di tengah masyarakat (Miratun \& Nugrahani, 2019).

Desa tertinggal harus berusaha sungguh-sungguh dan efektif dalam memanfaatkan sumber daya desa termasuk sumber daya manusia, sumber daya alam, dan sumber daya ekonomi/keuangan untuk mencapai IDM yang lebih besar dan masuk tipologi desa berkembang. Dari tiga komponen IDM yaitu, Indeks Ketahanan Sosial (IKS), Indeks Ketahanan Ekonomi (IKE), dan Indeks Ketahanan Lingkungan (IKL) yang memiliki nilai kurang agar ditingkatkan sebagai prioritas pembangunan dan pemberdayaan masyarakat desa (Suroso, 2020).

Pembangunan desa tertinggal akan mengalami percepatan menjadi desa berkembang apabila ada daya 
dukung dari stakeholders. Secara umum, desa memiliki sumber daya keuangan (anggaran) yang memadai, tetapi tidak semua masalah dapat dicukupi atau diselesaikan oleh desa. Oleh karena itu, peran stakeholders (Dinas/Instansi) terkait sangat dibutuhkan (Suroso, 2020).

Menurut RPJMN 2015-2019, usaha membangun desa tertinggal menjadi berkembang dimaksudkan untuk mengurangi jumlah desa tertinggal dan memperbanyak jumlah desa mandiri. Hal ini pun sesuai dengan salah satu misi RPJMD Kabupaten Mempawah Tahun 2020-2024 yaitu, menumbuhkan dan mengembangkan perekonomian desa guna menciptakan kemandirian masyarakat desa yang bertujuan meningkatkan kemandirian desa sebagai basis perekonomian masyarakat.

Selain dari faktor ekonomi, sosial, dan lingkungan dalam IDM, perlu dipertimbangkan faktor tata kelola pemerintahan dalam pembangunan desa. Hal ini karena hasil dari kegiatan ekonomi, sosial, dan lingkungan masih berkaitan dengan tata kelola desa (Setyowati, 2019).

Program pembangunan yang dilaksanakan di perdesaan akan berjalan baik dan menghasilkan kinerja sesuai dengan harapan apabila didukung oleh program peningkatan kinerja manajemen dan kelembagaan. Hal ini dimaksudkan untuk memenuhi kebutuhan perdesaan dan meningkatkan daya saing produk yang dihasilkan, sehingga dapat terwujud peningkatan pendapatan dan kesejahteraan masyarakat (Bachrein, 2010).

Desa hendaknya dijadikan wajah terdepan pemerintahan yang berhubungan langsung dengan rakyat Indonesia. Oleh karena itu, desa harus diupayakan sejauh mungkin mampu memperkuat identitas lokal yang berbasis pada nilai-nilai sosial budaya masyarakat setempat. Penguatan identitas lokal dan kearifan lokal akan memungkinkan desa berdiri kokoh yang tidak mudah tergerus oleh arus globalisasi. Peningkatan kesejahteraan masyarakat desa harus berjalan seiring dengan perlindungan adat yang telah tumbuh dan berkembang di dalamnya (Zuliansyah et al., 2020).

Untuk mendukung upaya pemerintah dalam mengubah desa sangat tertinggal dan desa tertinggal menjadi desa berkembang serta dari desa berkembang dan desa maju menjadi desa mandiri, Provinsi Kalimantan Barat telah menerbitkan Peraturan Gubernur Kalimantan Barat Nomor 1 Tahun 2019 tentang Percepatan Peningkatan Status Kemajuan dan Kemandirian Desa. Peraturan ini diterbitkan sebagai pedoman bagi setiap daerah Kabupaten/Kota di Provinsi Kalimantan Barat dalam menjalankan strategi percepatan peningkatan status kemajuan dan kemandirian desa dalam rangka pemerataan pembangunan di Kalimantan Barat. Pergub ini dibuat agar pelaksanaan strategi tersebut bisa berjalan dengan baik dan terkoordinir.

Terkait dengan kemajuan dan kemandirian desa, Peraturan Daerah Kabupaten Mempawah Nomor 4 Tahun 2020 tentang RPJMD Kabupaten Mempawah Tahun 2020 - 2024 menyebutkan salah satu misinya yaitu, "Menumbuhkan dan mengembangkan perekonomian desa guna menciptakan kemandirian masyarakat desa yang bertujuan meningkatkan kemandirian desa sebagai basis perekonomian 
masyarakat". Potensi sumberdaya alam, laut dan darat/tanah sebagian besar berada di wilayah perdesaan. Namun, karena keterbatasan kualitas sumberdaya alam dan dana, potensi tersebut belum seluruhnya dapat dikelola. Untuk mendukung pembangunan di desa, maka diusunglah berbagai kebijakan berbasis desa misalnya, Kampung KB, Sarjana Masuk Desa, Dokter Desa, BUMDes, dan lain-lain diikuti peningkatan Alokasi Dana Desa (ADD) dan Dana Desa (DD).

Dana desa dapat digunakan untuk membantu meningkatkan pemberdayaan masyarakat dalam bentuk fisik misalnya, infrastruktur jalan ke permukiman warga terisolir, infrastruktur jalan pertanian, pembangunan air bersih, dan dalam bentuk non fisik misalnya bimbingan teknis untuk para perangkat desa dan pemberdayaan kesejahteraan keluarga (Hulu et al., 2018).

\section{METODE}

Penelitian ini menggunakan metode studi literatur yang berkaitan dengan perkembangan status desa dan kemandirian desa berdasarkan IDM dari tahun 2018 sampai tahun 2000 di Kabupaten Mempawah dan melakukan wawancara dengan narasumber terkait perkembangan IDM Kabupaten Mempawah. Data dianalisis secara deduktif kualitatif.

\section{HASIL DAN PEMBAHASAN}

\section{a. Status Desa dan Kemandirian Desa di Kabupaten Mempawah Tahun 2018}

Kabupaten Mempawah telah melakukan verifikasi status kemandirian dan kemajuan desa berdasarkan IDM sejak tahun 2018. Pada tahun 2018, dari 60 desa yang ada di Kabupaten Mempawah ternyata tidak ada desa yang berstatus sebagai desa mandiri. Sebagian besar desa di kabupaten ini masuk dalam kategori desa berkembang dan desa tertinggal, dan sisanya masuk pada kategori desa maju dan desa sangat tertinggal (Tabel 2).

Table 2. Rekapitulasi IDM 2018

\begin{tabular}{|c|c|c|c|}
\hline No & $\begin{array}{c}\text { Status IDM } \\
2018\end{array}$ & $\begin{array}{l}\text { Jml } \\
\text { Desa }\end{array}$ & Persentase \\
\hline 1. & $\begin{array}{l}\text { Sangat } \\
\text { Tertinggal }\end{array}$ & 2 & $3,33 \%$ \\
\hline 2. & Tertinggal & 21 & $35 \%$ \\
\hline 3. & Berkembang & 30 & $50 \%$ \\
\hline 4. & Maju & 7 & $11,67 \%$ \\
\hline 5. & Mandiri & 0 & $0 \%$ \\
\hline & Jumlah & 60 & $100 \%$ \\
\hline
\end{tabular}

Merujuk kepada data tahun 2018 , desa dengan status sangat tertinggal di Kabupaten Mempawah berada di daerah yang relatif terpencil yaitu, Desa Bumbun dan Desa Suak Barangan di Kecamatan Sadaniang. Nilai status kedua desa tersebut di bawah standar status desa sangat tertinggal. Status desa-desa tersebut lebih banyak dipengaruhi oleh tingkat perekonomian atau nilai dimensi ketahanan ekonomi yang relatif rendah. Pada aspek ketahanan ekonomi, desa-desa ini masih dinilai kurang dalam tingkat keragaman produksi masyarakat dan sektor perdagangan di permukiman (warung dan mini market). Selain itu, pada variabel lembaga perekonomiannya misalnya, desa-desa ini masih dinilai memiliki kekurangan akses ke lembaga perkreditan, pusat perdagangan, distribusi logistik, dan lembaga keuangan. Kebanyakan jalan desa masih berupa jalan tanah dan rusak, dan kondidisi ini menjadi salah satu factor rendahnya akses masyarakat. 
Dilihat dari dimensi ketahanan sosial dan dimensi ekologi, Desa Bumbun dan Desa Suak Barangan juga tidak lebih tinggi dari desa-desa yang lain. Secara sosial kedua desa tersebut memiliki tingkat pendidikan (akses ke pengetahuan serta pendidikan formal dan non formal) yang relatif rendah. Selain itu, fasilitas permukiman seperti air bersih, sanitasi, listrik, dan informasi-komunikasi juga relatif rendah.

Dilihat dari status IDM 2018, desa dengan status tertinggal berjumlah 21 desa. Status desa seperti ini lebih banyak dipengaruhi oleh dimensi ketahanan ekonomi yaitu, kondisi desa sangat tertinggal namun masih lebih baik. Dari dimensi ekonomi, desa-desa ini relatif jauh dari akses ke pusat pelayanan perdagangan dan lembaga perekonomian, dan diperburuk oleh kualitas jalan. Dari dimensi sosial yaitu kesehatan, pendidikan, dan modal sosial relatif lebih baik, demikian juga dari dimensi ekologi yaitu kualitas lingkungan dan potensi bencana alam relatif masih baik.

Terdapat 30 desa dengan status berkembang di tahun 2018. Desa-desa dengan status ini umumnya dipengaruhi oleh dimensi ketahanan ekonomi yang relatif lebih rendah. Dilihat dari dimensi ketahanan sosial yaitu, akses terhadap pelayanan kesehatan, pendidikan, dan modal sosial, keadaannya masih relatif baik. Secara ekologi yaitu kualitas lingkungan masih relatif baik, sedangkan potensi rawan bencana alam juga kurang.

Kemudian, status IDM desa maju disematkan pada 7 desa di kabupaten ini. Penilaian ini didasarkan kepada pemenuhan variabel dimensi ketahanan sosial, ketahanan ekonomi, dan ekologi, desa-desa tersebut secara merata relatif sudah lebih baik. Secara sosial, akses masyarakat terhadap pendidikan dan kesehatan sudah lebih dekat dan mudah dijangkau. Selain itu, desa-desa ini juga mempunyai keunggulan daripada desa-desa dengan status IDM lebih rendah, yaitu adanya kebiasaan gotong-royong, ketersediaan ruang terbuka publik, fasililtas olahraga, toleransi, keamanan, dan kesejahteraan sosial. Permukiman masyarakat pada desa-desa maju sudah lebih baik dalam mengakses air bersih. Mereka juga memiliki sanitasi yang baik, akses listrik, dan informasikomunikasi. Desa maju secara ekonomi lebih dekat dalam akses ke pusat perdagangan dan perekonomian dan kondisi jalan akses pun lebih baik. Secara ekologi, kualitas lingkungan lebih baik dan potensi bencana alam kurang.

\section{b. Status Desa dan Kemandirian Desa di Kabupaten Mempawah Tahun 2019}

Merujuk kepada data IDM tahun 2019, desa-desa di Kabupaten Mempawah mengalami perubahan nilai IDM. Perubahan tersebut lebih banyak pada kenaikan nilai status IDM. Beberapa desa mengalami kenaikan status dari sangat tertinggal menjadi tertinggal, dari tertinggal menjadi berkembang, serta dari berkembang menjadi maju. Mulai tahun 2019 di Kabupaten Mempawah tidak ada lagi desa dengan predikat sangat tertinggal, bahkan sudah ada beberapa desa masuk predikat desa mandiri (Tabel 3). Perbaikan status ini dikarenakan Pemerintah Kabupaten Mempawah melakukan intervensi 
pembangunan infrastruktur di desadesa seperti pembangunan prasarana kesehatan, pendidikan, dan akses ke air bersih, serta pembangunan aksesnya.

Pada tahun 2019, Desa Bumbun yang sebelumnya sangat tertinggal naik dua tingkat menjadi berkembang, sedangkan Desa Suak Barangan naik satu tingkat menjadi desa tertinggal. Desa yang tidak mengalami perubahan status adalah Desa Ansiap yaitu, tertinggal.

Table 3. Rekapitulasi IDM 2019

\begin{tabular}{llrr}
\hline No. & $\begin{array}{c}\text { Status IDM } \\
\mathbf{2 0 1 9}\end{array}$ & $\begin{array}{c}\text { Jumlah } \\
\text { Desa }\end{array}$ & Persentase \\
\hline 1 & Sangat & 0 & $0 \%$ \\
2 & Tertinggal & 2 & $3,33 \%$ \\
3 & Tertinggal & 7 & $11,67 \%$ \\
4 & Berkembang & 35 & $58,33 \%$ \\
5 & Maju & 16 & $26,67 \%$ \\
\hline Jumlah & $\mathbf{6 0}$ & $\mathbf{1 0 0 \%}$ \\
\hline \multicolumn{2}{l}{ Sumber: hasil verifikasi IDM 2019 }
\end{tabular}

Sedikit berbeda dengan tahun 2018, di tahun 2019 secara rata-rata dimensi ketahanan ekonomi desa-desa di Kabupaten Mempawah mengalami kenaikan. Dimensi ketahanan ekonomi $(31,5 \%)$ berada di urutan kedua setelah dimensi ketahanan sosial $(38,28 \%)$, dan yang terakhir yaitu dimensi ekologi atau ketahanan lingkungan $(30,22 \%)$ dalam mempengaruhi nilai IDM.

Pada tahun 2019, dimensi ketahanan ekonomi desa-desa di Kabupaten Mempawah telah mengalami peningkatan. Penyebabnya adalah bertambahnya keanekaragaman jenis kegiatan penduduknya, munculnya lembagalembaga ekonomi misalnya warung makanan, pertokoan, akses ke perkreditan, BUMDES / BUMDESMA dan diperbaikinya akses penduduk ke pusat perdagangan. Untuk jalan akses dapat dilihat dengan diperbaikinya jalan desa yang di beberapa ruasnya sudah menjadi jalan aspal.

Dimensi ketahanan sosial di tahun 2019 ini merupakan faktor yang paling banyak menyumbang dalam peningkatan nilai IDM. Dengan kualitas jalan desa yang membaik, berefek langsung kepada akses ke kesehatan dan pendidikan yang juga membaik. Pada modal sosial yaitu solidaritas sosial, toleransi, keamanan, kesejahteraan sosial umumnya tidak banyak mempengaruhi dimenisi ketahanan sosial karena relatif tidak banyak perubahan. Permukiman mengalami peningkatan dengan hadirnya kegiatan penyediaan akses ke air bersih (Pamsimas dan SPAM desa), penyediaan listrik ke desa (misalnya Desa Bumbun di Kecamatan Sadaniang), dan penyediaan akses informasi dan informasi yang ditandai dengan penyediaan akses jaringan telepon seluler dan internet yang disediakan oleh beberapa provider sampai ke desa-desa.

Dimensi ekologi atau ketahanan lingkungan mengalami penurunan dalam kontribusi peningkatan nilai IDM tahun 2019. Hal ini disebabkan oleh kejadian bencana alam yang terjadi di tahun 2019 seperti banjir dan kebakaran lahan. lain adalah kurangnya ketersediaan peralatan mitigasi bencana misalnya, alat pemadam kebakaran desa dan peta rawan bencana di desa. 


\section{c. Status Desa dan Kemandirian Desa di Kabupaten Mempawah Tahun 2020}

Pada tahun 2020, desa-desa di Kabupaten Mempawah mengalami perubahan nilai IDM. Perubahan tersebut lebih banyak ke arah kenaikan nilai status IDM. Beberapa desa mengalami kenaikan status dari berkembang menjadi maju, dan beberapa desa dari maju menjadi mandiri. Namun, meskipun beberapa desa mengalami peningkatan status IDM, ternyata masih terdapat dua desa yang tergolong desa tertinggal, sebagaimana status IDMnya di tahun 2019. Desa-desa tersebut adalah Desa Ansiap dan Desa Suak Barangan di Kecamatan Sadaniang. Kedua desa ini memang termasuk daerah pedalaman.

Terdapat pengurangan jumlah desa yang berstatus berkembang dari 7 desa di tahun 2019 menjadi 6 desa di tahun 2020. Hal ini disebabkan Desa Sungai Kunyit Hulu di Kecamatan Sungai Kunyit mengalami peningkatan statusnya menjadi desa maju. Desa ini walaupun berlokasi relatif jauh dari pusat pelayanan, namun telah mengalami peningkatan dalam dimensi ketahanan sosial dan ketahanan ekonomi yang ditandai dengan ada perbaikan jalan sehingga akses ke air bersih, kesehatan, lembaga ekonomi, dan pendidikan meningkat. Modal sosial masyarakat berupa gotong royong, kegiatan olahraga, keamanan, toleransi, dan kesejahteraan juga mengalami peningkatan meskipun dimensi ekologi atau ketahanan lingkungan tidak mengalami perubahan.

Pada tahun 2020 terjadi pengurangan jumlah desa yang berstatus maju, yaitu dari 35 desa di tahun 2019 menjadi 23 desa di tahun 2020. Penurunan jumlah ini terjadi karena beberapa desa tersebut telah meningkat statusnya menjadi Mandiri.

\begin{tabular}{llrr}
\multicolumn{4}{c}{ Table 4. Rekapitulasi IDM 2020} \\
\hline No. & $\begin{array}{c}\text { Status IDM } \\
\mathbf{2 0 2 0}\end{array}$ & $\begin{array}{c}\text { Jumlah } \\
\text { Desa }\end{array}$ & Persentase \\
\hline 1 & Sangat & - & $0,00 \%$ \\
2 & Tertinggal & 2 & $3,33 \%$ \\
3 & Tertinggal & 6 & $10,00 \%$ \\
4 & Berkembang & 23 & $38,33 \%$ \\
5 & Maju & 29 & $48,33 \%$ \\
\hline Jumlah & $\mathbf{6 0}$ & $\mathbf{1 0 0 , 0 0 \%}$ \\
\hline \multicolumn{2}{r}{ Sumber: hasil verifikasi IDM 2019 }
\end{tabular}

Secara rata-rata di tahun 2020, dimensi ketahanan sosial yang paling banyak berkontribusi dalam penentuan nilai IDM (36,95\%), disusul dimensi ekologi atau ketahanan lingkungan berada di urutan ke dua $(31,97 \%)$, sedangkan dimensi ketahanan ekonomi berada di urutan ke tiga $(31,08 \%)$. Peningkatan penilaian pada dimensi ketahanan sosial terjadi karena bertambahnya jumlah desa yang mengalami peningkatan akses di bidang kesehatan, pendidikan/ pengetahuan, modal sosial, dan permukiman. Pada bidang kesehatan, akses dan pelayanan kesehatan semakin baik ditandai dengan waktu tempuh ke pusat layanan kesehatan yang semakin cepat, dan peningkatan ketersediaan tenaga kesehatan, tingkat aktifitas posyandu, keberadaan kampung $\mathrm{KB}$, dan tingkat kepesertaan BPJS di desa. Selain itu, bidang modal sosial tetap terjaga baik dengan ditandai dengan ketersediaan fasilitas/lapangan olahraga berikut kelompoknya, ruang terbuka publik, kegiatan gotong-royong, tetap terjaganya toleransi, rasa aman. Bidang permukiman mengalami 
peningkatan berupa semakin baiknya akses ke air bersih, sanitasi yang difasilitasi oleh Pamsimas dan SPAM desa, bertambahnya akses ke listrik dan informasi komunikasi (kepemilikan smartphone dan sinyal yang relatif kuat) di desa-desa.

Pada tahun 2020 secara rata-rata dimensi ekologi atau ketahanan lingkungan mengalami peningkatan karena di tahun ini terdapat peningkatan kualitas lingkungan yaitu kondisi air, tanah, dan udara di desa-desa. Hal ini juga disebabkan oleh berkurangnya kejadian dan potensi bencana yang dilengkapi dengan adanya mitigasi bencana di desa-desa. Dimensi ketahanan ekonomi juga lebih banyak mengalami peningkatan yang ditandai dengan perbaikan kualitas jalan desa yang semakin memberikan kemudahan akses penduduk ke pusat pelayanan dan perdagangan.

\section{KESIMPULAN}

Sejak tahun 2018 sampai tahun 2020, status desa dan kemandirian desa di Kabupaten Mempawah berdasarkan IDM terus mengalami peningkatan. Peningkatan ini merupakan kontribusi dari semakin baiknya aspek sosial, ekonomi, dan ekologi/ketahanan lingkungan. Peningkatan ini ditandai dengan munculnya beberapa desa dengan status IDM Maju dan Mandiri.

Di Kabupaten Mempawah, walaupun sudah tidak ada lagi desa dengan status sangat tertinggal, namun masih ada dua desa dengan status tertinggal. Kedua desa tersebut adalah Desa Ansiap dan Desa Suak Barangan yang lokasinya relatif terpencil di Kecamatan Sadaniang.

\section{REKOMENDASI}

Untuk meningkatkan status desa diperlukan intervensi dengan meningkatkan nilai dimensi ketahanan sosial, dimensi ketahanan ekonomi, dan dimensi ekologi/ketahanan lingkungan. Hal ini dapat diupayakan dengan meningkatkan nilai variabel yang berkaitan, yaitu dengan pembangunan dan peningkatan sarana prasarana kesehatan (Puskemas, Polindes, tenaga kesehatan), pendidikan (PAUD, sekolah, perpustakaan, tenaga pendidikan), serta aksesnya. Untuk mendukung peningkatan nilai pada dimensi ketahanan lingkungan, maka perlu dilaksanakan mitigasi bencana secara lebih intensif seperti menyediakan peta rawan bencana, sarana pemadam kebakaran, serta lokasi dan jalur evakuasi. Selain itu, juga perlu dibangun modal sosial di masyarakat berupa kerukunan, keamanan, dan semangat gotong royong. Kemudian, untuk desa-desa dengan status yang masih tertinggal dan berkembang perlu intervensi untuk meningkatkan statusnya, yaitu dengan melaksanakan hal-hal di atas secara lebih intensif.

\section{UCAPAN TERIMA KASIH}

Ucapan terima kasih disampaikan kepada Kepala Bappeda, Kabid Pengendalian, Fispra, dan Litbang Bappeda Kabupaten Mempawah yang telah memberi tugas untuk melakukan penelitian ini, dan Bu Alfi Tenaga Ahli Bidang Pelayanan Sosial Dasar Kabupaten Mempawah yang telah berkenan memberikan informasi yang diperlukan. 


\section{DAFTAR PUSTAKA}

Bachrein, S. (2010). Pendekatan Desa Membangun di Jawa Barat: Strategi dan Kebijakan Pembangunan Perdesaan. IAARD E-Journal, 8(2), 133-149.

Hamidi, H., Setijonegoro, F. N., Fujitriartanto, Sa'id, A., Harioso, Huda, Hardiyanto, A., Waluyanto, B., Lubis, I. S. G., Setiawan, D., Prayitno, H., \& Mu'arofah, A. F. (2015). Indeks Desa Membangun. Kementerian Desa, Pembangunan Daerah Tertinggal dan Transmigrasi.

Hulu, Y., Harahap, R. H., \& Nasution, M. A. (2018). Pengelolaan Dana Desa dalam Pemberdayaan Masyarakat Desa. Jurnal Pendidikan IImu-IImu Sosial, 10 , 146-154. https://doi.org/https://doi.org/10.241 14/jupiis.v10i1.9974.g9070

Miratun, N. A., \& Nugrahani, K. (2019). Strategi Mempercepat Pembangunan Desa Mandiri: Studi Di Desa Kemadang Gunungkidul. Jurnal Pemberdayaan Masyarakat: Media Pemikiran Dan Dakwah Pembangunan, 2(1), 169-188. https://doi.org/10.14421/jpm.2018.0 21-09

Peraturan Menteri Desa, Pembangunan Daerah Tertinggal dan Transmigrasi No. 2 Tahun 2016 tentang Indeks Desa Membangun, (2016).

Peraturan Daerah Kabupaten Mempawah Nomor 4 Tahun 2020 tentang RPJMD Kabupaten Mempawah Tahun 2020 - 2024, (2019).
Peraturan Gubernur Kalimantan Barat No. 1 Tahun 2019 tentang Percepatan Peningkatan Status Kemajuan dan Kemandirian Desa, (2019).

Sari, N., \& Oktavianor, T. (2020). Indeks Desa Membangun (IDM) di Kabupaten Barito Kuala. JPP: Jurnal Administrasi Publik Dan Pembangunan, 2(1).

Setyowati, E. (2019). Tata Kelola Pemerintahan Desa Pada Perbedaan Indeks Desa Membangun (IDM): Studi Tiga Desa Di Kabupaten Malang. Jurnal Hukum \& Pembangunan, 53(9), 1689-1699.

Sukarno, M. (2020). Analisis Pengembangan Potensi Desa Berbasis Indeks Membangun Desa (IDM)(Studi Kasus: Desa Ponggok, Kecamatan Palohharjo, Kabupaten Klaten). Prosiding Seminar Edusainstech FMIPA UNIMUS 2020, 6, 533-541.

Suroso. (2020). Kebijakan Pembangunan Desa Tertinggal Berbasis Indeks Desa Membangun (IDM) dan Potensi Lokal. Jurnal Litbang: Media Informasi Penelitian, Pengembangan Dan IPTEK, 16(1), 47-62.

https://doi.org/10.33658/jl.v16i1.167

Ulumiyah, I., Gani, A. J. A., \& Mindarti, L. I. (2013). Peran Pemerintah Desa Dalam Memberdayakan Masyarakat Desa (Studi Pada Desa Sumberpasir Kecamatan Pakis Kabupaten Malang). Jurnal Administrasi Publik Mahasiswa Universitas Brawijaya, 1(5), 890899. 
Zuliansyah, A., Malik, A., \& Adi, B. L. (2020). Membangun Desa Masa Depan yag Ideal: Kendala dan Kebutuhan Pemerintahan Desa dalam Mengimplementasikan Undang-Undang Desa. Al Mu'awanah: Jurnal Pengabdian Kepada Masyarakat, 1(1), 19-28. 